\title{
Japanese Hospital-Ships
}

\section{Dr. Georges Varenne}

To cite this article: Dr. Georges Varenne (1905) Japanese Hospital-Ships, Royal United Services Institution. Journal, 49:325, 308-311, DOI: 10.1080/03071840509418685

To link to this article: http://dx.doi.org/10.1080/03071840509418685

曲 Published online: 11 Sep 2009.

Submit your article to this journal $\pi$

Џll Article views: 5

Q View related articles $₫$ 


\title{
JAPANESE HOSPITAL-SHIPS.
}

\author{
By Dr. GEORGES YARENNE, Surgenn of the French Nary.
}

Translated by permission from the Archives de Médecine Narale By Fleet Surgeon C. Marsh Beadneld, R.N.

IN the course of her present military operations, Japan is utilising a system of removing the sick and wounded, the organisation and modus operandi of which are well worth the attention of all who appreciate the indispensability of such a service in modern warfare.

The following article will give the reader an idea of the degree of perfection reached by the Japanese hospital-ships, and he will, no doubt, realise that the marvellous faculty of assimilation, characteristic of the Japanese race, is blended with an originality and initiative which European nations may well envy.

The removal of the sick and wounded from the scene of action to the Japanese hospitals is undertaken by two bodies:-

1. The medical department of the Japanese Navy.

2. The Japanese Red Cross Society.

\section{State Hospital-Ships.}

The State employs two hospital-ships, the "Kobe-Maru" and the "Saiko-Maru." These two sister-ships are of English construction, have a displacement of 3,000 tons, and a speed of 15 knots.

They sail under the Japanese mercantile flag, and fly the Geneva Red Cross at the main-mast. These vessels, which in peace time belong to the great Nippon Yusen Kaisha Steamship Company, are, in times of war, provided with a special complement; they retain their own staff and merchant crew for the purpose of navigating the ship and carrying on the daily routine in connection with it; but they receive in addition a medical personnel thus composed:-

Personnel.-One Principal Medical Officer (Gouni-Sho-Kan);

One Fleet Surgeon (Gotmi-Daï);

One Staff Surgeon (Gouni-Tchu);

Three Surgeons (Gouni-Slo);

Two Assistant Surgeons (Gouni-Kohoscï);

Two Dispensers (Yakous);

Thirty Sick-Bertlı Attendants.

On board these ships there are no women-nurses, whereas the Red Cross Hospital-Ships, which we will describe further on, are supplied with a greater number of female than male nurses.

A rrangements.- Sick and wounded officers are quartered in rooms, each containing, as a rule, two bunks. Ordinary cases are placed in 
bunks, supported by iron braces and arranged one above the other in two rows, on large and well ventilated decks. The bulkheads are covered with a paint called Japonaise, which can be washed with boiling water. In addition to these quarters, there is a room set apart for the isolation of infectious cases, and a cabin for mental cases.

All these compartments occupy the after-portion of the deck, and a fraction of the mid-ship portion. Forward, are situated the quarters of the nursing staff, a steam laundry, a large disinfecting stove, and a freezing chamber. In the central part of the deck will be found the operating theatre and dressing room, both well lighted by large port-holes. The walls are coated with white enamel, the instruments are of the latest and best pattern.

Many of the surgical instruments are of Japanese construction, though all are copies of French and German ones. The whole of this department, like the rest of the ship, is kept scrupulously clean, in a manner essentially Japanese. The dressings are almost all of Japanese make, as well as the drugs, though a few of these latter are procured from Germany.

Close to the operating theatre is a laboratory, completely equipped for radioscopy and sciagraphy. Constant use of this laboratory has been made since the outbreak of the war, and we need not insist upon the innumerable services, which, in several circumstances, radioscopy has rendered to surgery.

Upou the upper deck is situated the laboratory of pathological antomy and bacteriology, a well lighted chamber containing a very complete stock of instruments, also microscopes of French or German make. Finally, upon this deck are the officers' quarters, ward-room and accessory rooms (spirit and provision rooms, kitchens, etc). The store-rooms and other compartments having no particular bearing on this subject, need no description.

The Sick and Wounded.-A hospital-ship of this type is able to receive a maximum number of sick and wounded as follows :-

Officers, 30 .

Ordinary cases, 200.

Infectious cases, 80.

The sick are kept in a condition of irreproachable cleanliness, and are fed in a manner that differs but little-from the feeding of the sailors of the Japanese Navy, except, of course, in the case of those on special diet. The State hospital-ships have been in constant use since the commencement of the war, and the surgeons of the Japanese Navy are unanimous in extolling both their utility and their splendid organisation. They attribute to these sources of immediate medical relief the very considerable lowering in the percentage of mortality amongst the sick and wounded of their armies. They are furthermore aided to a considerable degree in their arduous task by the hospitalships of the Japanese Red Cross Society, concerning which we shall now say a few words.

\section{Japanese Red Cross.}

Twenty-eight years ago, in the course of the civil war, some Japanese philanthropists founded, for the purpose of aiding the wounded, a society which ultimately adopted the articles of the Geneva Convention and became known as the Japanese Red Cross Socicty. At 
the present time this society has been brought up to the highest pitch of organisation. It is placed under the honorary directorship of Prince Kiven-ln, and under the effective presidency of Count Sano. Its members are divided into four categories:-

1. Members who have given a donation of 1,000 yen to the Society.

2. Members who have given a donation of 250 yen to the Society.

3. and 4. Members who have given a donation of 25 yen to the Society, or an annual subscription of threc yen for ten ycars.

Members of the different classes are granted medals and distinctive badges; foreigners are permitted to join the Society. The total number of members, which 28 years ago amounted to 38 , is at the present time 920,000. The total capital is $7,900,000$ yen; the total annual assessments are 2,310,000 yen. The sanitary departments of the Society are subdivided into 110 companies, each company comprising 4 surgeons and 40 male and female nurses. The total personnel einployed by the Japanese Red Cross in ambulance and health departments on board ship, is 3,099 , of whom 1,886 are female nurses, and 750 male nurses. The Socicty has, in addition, founded 320 University scholarships, to enable young men of scanty means to prosecute their medical or pharmaceutical studies, on the understanding that they are afterwards enrolled in the Red Cross corps. The Japanese are justly proud of the good services rendered by this Society. Foreigners, who have recently been to Japan, and who have seen the ambulances organiser by it, declare that the sick in them meet with admirable treatment.

Red Cross IIospital-Ships.-Two hospital-ships, the "HakuaiMaru" and the "Kosai-Maru," are, at the present time, employed by the Japanese Red Cross Society.

These vessels, which also belong to the Nippon Yusen Kaisha Company, have the same characteristics and almost the same internal economy as the "Kobe-Maru" and the "Saiko-Maru." It has, nevertheless, been stated by a Japanese Army surgeon, who has seen and compared the two services, that the State vessels are to be preferred. Be that as it may, the Red Cross lospital-ships have already given a good account of themselves in the Chino-Japanese war.

In the course of the operaticns now going on, they have rendered yeoman's service in carrying on an almost continuous to-and-fro transport between the military bases and the hospitals in Japan.

We had the opportunity of paying a visit to the "Hakuaï-Maru" at Chemulpo, on 2nd IIarch, 1904, when she came to that port for the purpose of removing some wounded from the shore-hospital to the Japanese hospital at Matsuyama. The ship was exquisitely clean, and the work was carried on without a hitch.

The wounded Russians, some of whom weie in a most critical condition, were looked after with the greatest care.

The persomnel of the Red Cross hospital-ship includes:-

One Fleet Surgecn.

Two Surgeons.

Two Assistant Surgeons, 
The Foreign Office appoints an oficer to be in charge of the administration, and probably, of the actual management of these vessels.

Lastly, 40 male and female nurses do the work of the wards.

The navigation and care of the ship are entrusted to the complement she possessed in peace time. These ships, which in March came to Chemulpo to fetch away the sick and wounded, have, since then, skirted the coast line, working hand-in-hand with the Army.

The naval hospitals, into which the different ships discharge their wounded, are situated at Matsuyama, Yokosuka, Kuré, Sasebo and Maïzuru. These hospitals belong to the medical department of the Navy; the medical officers were formerly trained in a special school, but are now chosen from amongst those medical men who have first studied in Japan and afterwards graduated in England or Germany.

It would be interesting to know exactly what lessons have been furnished by the present campaign to war-surgery. Unhappily, with the exception of photographs of doubtful utility published in some magazines, we have not been able to procure any enlightenment on this subject, the Japanese doctors showing great reserve in answering questions. At the same time, they acknowledge that their Army has suffered from cold, and paid a tribute to typhoid fever, and above all to beri-beri. A surgeon in the Japanese Navy assured us that kakké had absolutely disappeared on board the Inperial ships since the men had been provided, in lieu of the ration of rice, with a mixture which is quite as nutritious and perfectly harmless, to wit, barley and rice. The Army, on the contrary, not having adopted this empirical method, is still much troubled with kakké.

Such are the few facts which we thought would be interesting to record, regarding the administration of the Japanese hospital-ships during the operations of the present war. 